\title{
4
}

\section{Fisheries management}

The Barents Sea fish resources have for centuries constituted a main foundation for life in the northern parts of Fennoscandia. As follows from Chapter 1, these resources have since the mid-1970s been managed by a bilateral Norwegian-Russian regime, which in turn partly serves to spur the implementation of these countries' obligations in accordance with global and regional fisheries agreements. The main objective of this chapter is to discuss how Russian authorities since the break-up of the Soviet Union have implemented their international obligations in the fisheries sector of the country's northwestern region. How have federal and regional authorities coordinated the management of marine resources within the territorial waters of the Russian Federation, which according to the Constitution is an area of 'joint jurisdiction' (Article 72)? Have regional authorities abstained from interfering with the management of resources in the Exclusive Economic Zone (EEZ), since the Constitution defines this as a federal responsibility (Article 71)? To what extent is fisheries management still performed by the corporate structure of the 'fisheries complex', as this was done in Soviet times? Implementation is discussed with reference to more overarching political developments in the Russian Federation in general and Northwestern Russia in particular, and also seen in relation to the nature of the problem at hand and of the obligations to be implemented. A brief overview of the resource basis, with an emphasis on the joint Russian-Norwegian fish stocks, and main target groups is given before we embark upon the discussion. 


\section{Background: resource basis and industry structure}

\section{The Barents Sea fish resources}

The Barents Sea contains a rich abundance of fish stocks of a variety of species. The basis for the abundance of these fish resources is the high rate of plankton production in these waters, which provide food for large stocks of pelagic fish - i.e. fish living in the space between the sea floor and surface. The pelagic fish stocks, first and foremost capelin and herring, are in turn the prey of ground-fish, like cod, haddock and saithe. Both pelagic and groundfish serve as food for sea birds, marine mammals and people. Cod, capelin and herring are key species in the ecosystem. Cod feed on capelin, herring and smaller cod, while herring feed on capelin larvae. Periods with good recruitment to the cod and herring stocks and a reduced capelin stock tend to alternate with periods when herring is absent from the Barents Sea, while recruitment to the cod stock is moderate and capelin abundant.

The Barents Sea capelin (Mallotus villosus) stock used to be among the largest and most important fish stocks in the northeast Atlantic. One major trait of this stock is that large variations in individual growth from year to year lead to substantial fluctuations in stock size, which have considerable implications for the whole ecosystem. During the last quarter of the twentieth century, the total biomass fluctuated from close to 9 million tonnes (1975) to 0.2 million tonnes (1986). The capelin stock size was rather stable during the 1970s; in the 1980s, it decreased profoundly. Overfishing reinforced a natural downward fluctuation, bringing the stock close to total breakdown. Commercial fishing for capelin was halted in 1986, and the stock started to recover. Fishing was resumed again in 1991. A new collapse occurred in 1993. The stock recovered once again - at least partly. Fishing was resumed in 1999 for the first time since 1993. The quota that has been established is quite moderate.

The stock of Atlanto-Scandinavian herring (Clupea harengus) was the largest fish stock in European waters until its collapse in the late 1960s. The normal migration pattern from the North Sea to the spawning grounds off the Norwegian coast was broken in 1970. The stock had then been reduced to such an extent that the remaining fish found sufficient food off the Norwegian coast. The old migration pattern was only resumed in the mid-1990s. The stock has increased considerably in recent years, and herring catches in the 
North Sea are approaching those of the 1950s. However, the stock is now thought to be in decline. The cohort groups from 1993 onward seem to be weak. Some herring fry drift with the Gulf Stream into the Barents Sea each year, although their numbers are highly variable. Each age group spends three years here, feeding on capelin as they drift northward. While contributing to the total herring stock, the young herring of the Barents Sea may be considered a threat to the capelin. However, the herring also relieves the pressure on capelin, since it is itself preyed upon by cod. Although herring is not commercially exploited in the Barents Sea, its presence does affect the fishing in the area.

Norwegian-Arctic cod (Gadus morhua) spawn along the coastline of Norway from the age of seven. After spawning, they return to the Barents Sea. Fry of this species also drift into the northern parts of the Barents Sea. From the age of four, cod prey upon capelin as the latter species moves southward to its breeding grounds. The cod stock reached a total of some four million tonnes at the end of the 1960s. The stock decreased steadily throughout the 1970s to reach less than one million tonnes in 1984. Strong age groups were recruited in the years from 1983 to 1985 , but these cohorts were reduced in 1986-88 due to a lack of food and heavy fishing. Only at the beginning of the 1990s was the level of the late 1970s regained. This increase was mainly realised through quota regulation, which significantly moderated the fishing effort for cod. The stock of cod has shown a decline since 1993. Furthermore, stock estimates were regulated to lower levels in 1998, as scientists discovered that the method used previously had resulted in an overestimation of the stock. The quota for cod has been cut significantly in recent years.

The development of the Norwegian-Arctic haddock (Melanogrammus aeglefinus) stock in the Barents Sea tends to follow the same pattern as the cod. Having reached an all-time low in 1983-84, an increase was brought about by strong age groups from the years 1982-83. Another decline took place in the late 1980s. From 1990, recruitment improved markedly until 1995. In recent years, a modest overall decrease has been observed, but the spawning stock has increased. Fluctuations in the size of each age group are more significant for haddock than for cod, and the total stock is also considerably smaller. Thus, it is thought that it will be difficult to sustain a stable haddock fishery over time. 


\section{The Northwest Russian fishing industry}

The fishing industry of Northwestern Russia developed rapidly after the Russian Revolution in 1917. The Murmansk Trawl Fleet was established in 1920, and a development programme for the fisheries sector was launched in 1926 by the central Soviet power. The building of the Murmansk Fishing Combinate, which was to become the largest industrial fish processing complex in the Soviet Union, was started via this government initiative. As in other areas of the industrial sector in the Soviet Union, the sector principle was the guide used to organise the fisheries sector. This implied that the economic sphere of the union was divided into a certain number of sectors each of which was subordinated to its respective ministry. Apart from Khrushchev's attempts during the period 1957-64 to implement a territorial organisation of Soviet industry, the sector principle prevailed until the post-Soviet privatisation project started in 1992.

The association of fishing companies in the northern basin of the Soviet Union, Sevryba (meaning North Fish), was founded in 1965. It was given the status of General Directorate of the Soviet Ministry of Fisheries in Northwestern Russia. Similar bodies were set up in the Far East (Dalryba), the Baltics (Zapryba), the Caspian Sea (Kaspryba) as well as the Azov Sea and the Black Sea (Azcherryba, later re-named Yugryba). After several less comprehensive reorganisation efforts, Sevryba was made into a private joint-stock company in the autumn of 1992. Twenty-three companies with various core activities (ranging from shipowners, on-shore processing factories, a shipyard, research institutions, sales and supply organisations and various other firms) constituted the founders of the company. In April 1993, the Union of Private Fishery Enterprises in the North (Sever) was included in the A/O Sevryba structure. This union, founded in 1992, comprises more than 130 small private firms directly involved in or connected to the fishing industry in Northwestern Russia. However, only 70 of these are involved in the catching of fish, and no more than 18 of them have a cod quota in the Barents Sea. The core activity of most is not fishery; they have recourse to the catching or selling of fish primarily to raise funds for other types of production or trade.

The main structure of the fishing companies was upheld within the new institutional framework, which means that the majority of the approximately 450 fishing vessels located in Northwestern Russia are still controlled by a handful of fishing companies. The rest 
are distributed between kolkhozes (the collective fleet) and other socalled new small private fishing companies. The total number of vessels has been relatively stable since the early 1990s as few old vessels have been decommissioned (despite exceeding their anticipated lifetime), and few new vessels have been purchased. The existing fishing companies in Northwestern Russia can be placed in five different categories as seen in Table 4.1.

Table 4.1 The main user groups in the Northwest Russian fishing industry

\begin{tabular}{|c|c|}
\hline Inside Seuryba & Outside Sevryba \\
\hline $\begin{array}{l}\text { The old Soviet fleets (Murmansk } \\
\text { Trawl Fleet, Murmanrybprom, } \\
\text { Sevrybkholodflot, } \\
\text { Sevrybpromrazvedka, } \\
\text { Arkhangelsk Trawl Fleet Base, } \\
\text { Arkhangelskrybprom and } \\
\text { Karelrybflot) }\end{array}$ & $\begin{array}{l}\text { Thirty-one kolkhozes (fishing } \\
\text { collectives) organised in } \\
\text { Roskolkhozsoyuz } \\
\text { Eight kolkhozes organised in the } \\
\text { Union of Fishing Collectives in } \\
\text { the North }\end{array}$ \\
\hline $\begin{array}{l}\text { The Union of Private Fishing } \\
\text { Enterprises in the North (about } \\
130 \text { enterprises, of which } \\
\text { approximately } 55 \text { are involved } \\
\text { in fishing) }\end{array}$ & $\begin{array}{l}\text { The Union of Coastal Fishers } \\
\text { (about } 40 \text { enterprises } \\
\text { conducting fishery with } \\
\text { passive gear from vessels of } \\
\text { less than } 36 \text { metres) }\end{array}$ \\
\hline
\end{tabular}

Source: Hønneland and Nilssen (2001).

The old Soviet fleets consist mainly of medium-sized (50-70 metres) and large (over 70 metres) vessels, and each company owns between 30 and 95 vessels. All in all, there are 250-300 vessels. Before the dissolution of the Soviet Union, their main activity was the exploitation of pelagic species in distant waters and pelagic and demersal species in the Northern Atlantic Ocean and the Barents Sea. Now, they mainly fish for cod in the Barents Sea. The kolkhozes represent in some respects similar fleet structures as the traditional fishing companies, but have significantly fewer vessels, ranging from one to ten vessels each. They count around 80-100 vessels altogether. Nearly all are mid-sized (50-70 metres). An important characteristic of the fishing collectives is the wider diversification of their business activities than the other fishing companies and they are more engaged than the others in the catch of pelagic species. The new 
companies (including the coastal fishing fleet) have the smallest fishing fleet, both in terms of number and size, clearly limiting the cruising range of the vessels and, in practice, also the geographical sales markets of the fish. At present, the fleet consists mainly of fresh/salt fish combination vessels and some round freezer and fresh fish vessels. It counts some 100 vessels in all, including approximately 30 coastal fishing vessels of less than 50 metres. The rest are mid-sized (50-70 metres). It should be noted that the Russian perception of 'coastal fishing' is somewhat different from that found in its neighbouring Scandinavian countries. While a Norwegian 'coastal' fishing vessel normally has a crew of 1-3 persons and goes to port for delivery of catches each day, a Northwest Russian 'coastal' fishing vessel has a crew of more than a dozen men and stays at sea for a couple of weeks at a time before returning to deliver the catch.

The fisheries sector of the northern basin employed some 80,000 persons in the 1980s. The Murmansk Fish Combinate alone accounted for more than 6,000 employees in the land-based processing industry, while the largest fleet, the Murmansk Trawler Fleet, employed more than 17,000 persons at its peak. A sharp reduction in catches, and subsequently in employees, set in at the beginning of the 1990s. Throughout the 1990s, the total annual catch of the fishing fleet based in Murmansk Oblast (accounting for the bulk of the Northwest Russian fishing fleet) has dropped year by year, from 1.06 million tonnes in 1991 to 0.4 million tonnes in 1997. The main reason for this catch reduction is a major decline in distant fishing by the fleet of Northwestern Russia caused in turn by increased fuel costs. Adding to the problems of the land-based processing industry in Murmansk, Russian landings of fish abroad increased markedly during the same period. Russian landings of cod to Norway (fished in both Norwegian and Russian waters) reached 94,000 tonnes in 1992, while in 1988 they had only totalled 10,000 tonnes. Thereafter, the Russian landings in Norway increased further to nearly 150,000 tonnes around the mid-1990s. Since that time, there has been some reduction, and Russian deliveries of cod to Norway totalled 119,800 tonnes in 1998. The reason for this considerable increase in the export of fish is twofold. First, it became legally easier to export fish to Norway. Second, Northwest Russian fishers had to compensate both for the termination of state subsidies and an overall reduction in total catches. The main consequence of most Russian-caught fish being landed in Norway is a loss of job opportunities in Murmansk, 
both in the active fishing fleet and in processing industries ashore. The Murmansk Fish Combinate has been practically at a standstill since the mid-1990s. The total employment in the northern fishery basin is believed to have dropped to some $35-40,000$ people. ${ }^{1}$

\section{Premises for implementation}

Before we turn to the implementation activities of public authorities and others, the premises for implementation in this concrete case will be briefly discussed. Environmental and resource management problems vary in their nature; so do the international agreements aimed at their solution. Problems are of varying malignity; clearly, it is more difficult to solve a 'malign' environmental problem than a relatively 'benign' one, just as it is easier to solve a 'simple' than a 'complex' problem. The importance of the problem-creating activity to target groups also influences the potential for problem-solving. The greater the importance of the activity to the target groups, the more difficult it becomes, presumably, to make them change their behaviour. Moreover, one can assume that the potential for successful implementation depends on possibilities for monitoring target behaviour. It is easier and less costly to detect violations if the activity is concentrated in one or a few locations than if it is widely scattered. Finally, the nature of the agreements to be implemented influences the potential for success. In particular, it is more difficult to achieve full implementation of agreements the more specific and ambitious they are.

\section{Nature of the problem}

As demonstrated above, the Barents Sea contains a variety of fish species at various levels of the food chain. The state of species at one level is dependent upon the state of species at levels below and above. For instance, the state of the ground-fish stocks at any particular time depends on the level of the pelagic stocks as well as of the marine mammals in the area. Hence, the size of the Norwegian-Arctic cod stock decreases in times with little herring and capelin in the Barents Sea and when the occurrence of seal and whale is high. Moreover, the different species are sensitive to changes in their natural environment, e.g. fluctuations in the water temperature. A picture emerges of a highly 'complex' problem area: first, the problem is not influenced by human activity alone. Second, it consists of numerous causal 
connections about which human knowledge is imperfect. Third, to the extent such knowledge is available, the potential for human manipulation is limited. Nevertheless, it should be emphasised that it is only human action that can seriously harm the fish stocks in question. With the development of ever more efficient catch methods in the post-World War II era, it has become technically possible to bring the Barents Sea fish stocks to extinction.

At the moment of writing, the state of several Barents Sea fish stocks - among them the important Norwegian-Arctic cod stock is, if not catastrophic, then at least pretty serious. What is the potential for their recovery? Are target groups willing to sacrifice rewards from valuable catches? The most important aspect here is that the targets of public regulatory measures (emanating partly from international commitments) are the same people that are suffering from the problem. This makes the potential for effective implementation better than in many cases of classical environmental problems where the polluters are not the same as those suffering from the pollution. On the other hand, the 'penalty' makes itself felt only some time after the problem has been 'created', a circumstance that is supposed to reduce the willingness of targets to abstain from immediate benefits in order to contribute to implementation.

The problem-causing activity is also of great importance to the target groups in question. The fishery is a key industry in Northwestern Russia, which has concrete and symbolic implications at both individual and regional level. In Soviet times, Northwest Russian fisheries were significant in terms of food supplies not only at the regional, but also at the union level. Today, when much of the fish caught by Northwest Russian fishing vessels is delivered abroad, the fisheries are primarily of importance for regional authorities in terms of employment and revenue. Although both catches and employment have been significantly reduced since Soviet times, the fisheries sector is still a cornerstone of the regional economy. Symbolically, many inhabitants of Northwestern Russia still think of Murmansk as the 'fishery capital' of Russia. It might be assumed that the actual and symbolic importance of the fisheries to the region reduces the potential for successful implementation of international obligations that require a reduction in catches, in particular during the present economic crisis in the region.

At the individual level, the potential for personal economic gain from fishing activities has increased substantially since the early 
1990s, when the fishery enterprises were privatised and it became possible to sell the catches abroad. Hence, it can be argued that the fishery has become more important to the individual fishers than was the case in Soviet times, when their wages were only very loosely dependent on the amount of fish caught. ${ }^{2}$ The political and economic instability in Northwestern Russia since the early 1990s might have further reduced the propensity of fishers in the region to give priority to the long-term welfare of the fish stocks over shortterm private gain. The combination of political and economic insecurity on the one hand and the possibility of rapid personal profit on the other significantly increases the 'malignity' of the problem at hand; fishers in such a situation are supposedly far more difficult to regulate with a view to increasing the long-term common good (which is most often the objective of regulatory measures at both national and international level) than fishers with prospects of a financially secure future.

The potential for monitoring target activities may in this case be characterised as relatively good. ${ }^{3}$ The number of targets is limited, but they do operate over a rather large area. The chance of detecting violations also varies with the actual type of violation. ${ }^{4}$ Effective monitoring is possible, but costly. In the current financial situation in Russia, it has proven difficult. We return to this topic later in the chapter.

In sum, the problem appears to be not particularly malign in itself, but present circumstances give grounds for concern. On the one hand, the problem is complex, but 'solvable' by manipulation of human activities (since natural phenomena alone can hardly bring the fish stocks to extinction). Moreover, the number of targets is limited and, most importantly, the targets are also the main 'losers' if implementation fails. On the other hand, the problem-creating activities are of great importance both to the individual targets and to the economy of the region, which, presumably, would make it more difficult to achieve behavioural change that supports the implementation of Russia's international obligations in fisheries management. Political instability and economic hardships may also increase the propensity of targets to think short-sightedly, reducing the clout of the authorities' argument that non-compliance will eventually lead to a reduction in stock sizes that will not be in the target groups' long-term interests. 
Nature of the commitments

Chapter 1 describes the bilateral Norwegian-Russian regime for fisheries management in the Barents Sea and how it is partly nested in regional and global instruments. A striking feature in recent years has been the tendency to co-ordinate a growing number of regulatory measures of national responsibility in the bilateral regime. In particular, the establishment in 1993 of the Permanent Committee has furthered this end. During the latter half of the 1990s, regulatory matters such as the closing and opening of fishing grounds and satellite monitoring of fishing vessels have been codified by bilateral agreement in the Permanent Committee. New regulatory measures such as compulsory use of selection grid by fishing vessels, have also been introduced by this body. From the start in the mid-1970s, the bilateral regime has taken care of the most important regulatory mechanism of the Barents Sea fisheries, namely the establishment of total allowable catches (TACs) of the most important fish stocks in the area. All agreements between the two parties are binding.

Hence, Russia's international obligations related to fisheries management in the Barents Sea - or to be more precise, to the activities of the Northwest Russian fishing fleet ${ }^{5}$-are quite specific. To a large extent, the development of concrete regulatory measures takes place at the interface between obligations following from international agreements and federal standards to be applied also in the other fishery basins of the Russian Federation. Often, this makes it difficult to judge whether a particular measure emanates from the international regime or would have appeared through the national regulatory process independently of the state's international obligations. In this context, we perceive as Russia's international obligations all concrete measures codified through some sort of inter-state agreement, ranging from the general provisions of the global fisheries instrument (see Chapter 1) to concrete regulatory standards agreed upon by Russia and Norway in the Permanent Committee of the bilateral regime.

\section{Public authorities' implementation activities}

National implementation of international obligations starts with the incorporation in national legislation of requirements necessary to bring target behaviour into accordance with these obligations. Action must thereafter be taken by public authorities to enforce such requirements; it is this type of action we refer to as 'implementation 
activities'. In a Russian context, keeping in mind the 1993 Constitution's definition of resource management in the territorial waters of the Russian Federation as a 'joint responsibility' between the centre and federal subjects, these activities are expected to involve both federal and regional authorities. After a brief comment on the status of implementation in national legislation, changes in the role of federal authorities, regional authorities and federal agencies in the region in the 1990s are set out. Emphasis is on formal and actual role in the implementation process. The issue of implementation performance - whether implementation is achieved or not - is occasionally referred to here, but will be more thoroughly discussed in the last section of this chapter. We remind the reader that unless otherwise specified, all information is based on personal interviews with representatives of Russian fishing industry and fisheries management. In order to protect our interviewees from untoward repercussions, the concrete interviews are not indicated in the text (see pp. 17-18 on methodology in Chapter 1).

\section{Implementation in national legislation}

In Chapter 3, we observed that post-Soviet Russian politics have evolved in a virtual legal vacuum. Although a new constitution was in place as early as in 1993, the elaboration of a complementing legal framework has been slow and fumbling, partly as a consequence of the continuous conflict between the presidential administration and the Federal Parliament. The centre-region tension has also hampered the legislative process. The Parliament's upper house, the Federation Council - consisting of the leaders of the executive and legislative authorities of Russia's 89 federal subjects ${ }^{6}$ - has often rejected bills after they have passed the necessary readings in the state duma.

Since the early 1990s, a law on Russian fisheries and the protection of maritime biological resources of the Russian Federation has been under preparation by the Federal Parliament. After having been rejected several times, the bill was finally approved by the state duma on 7 July 2000. However, the Federation Council a few weeks later refused to vote over it due to strong disagreement among the leaders of the different regions. A working group was established to review the most 'burning' issues of the draft. The Governor of Murmansk Oblast and the President of the Republic of Karelia, who had both emerged as strong opponents of this version of the bill, were 
represented on the working group. When the Federal Parliament finally passed the bill in the spring of 2001, the President refused to sign it due to alleged inconsistency with other federal legislation. The bill was returned to the Federal Parliament for further clarification.

The centre-region tension was allegedly a main hindrance to reaching agreement on the Fisheries Act in the Federal Parliament. ${ }^{7}$ The present draft foresees the continuation of federal control over fisheries management, including the economically important quota allocation. It also evoked fear among regional actors of the introduction of payment for quota shares, increase in the amount of quotas sold to foreign shipowners and stricter control by more federal agencies than those already involved in the enforcement of fisheries regulations.

The fact that a federal fisheries act has not yet been adopted does not imply that Russian fisheries management takes place in a total legal vacuum. The Law on the Russian Exclusive Economic Zone was adopted in 1998 (Russian Federation 1998), laying the legal foundation for state enforcement in the EEZ. More importantly, a range of fisheries management issues are regulated by presidential decree, governmental resolution and management decisions at lower levels of the legal hierarchy. ${ }^{8}$ The problem is by no means a lack of transformation of international commitments into national legislation; on the contrary. An extremely large amount of presidential decrees and governmental resolutions are issued - in the fisheries sector as well as other sectors of Russian politics and economy - but they are simply not enforced. There is abundant anecdotal evidence of decrees and resolutions concerning fisheries management for which not even the slightest enforcement attempt has been made; hence, they can at best be interpreted as symbolic expressions of political will. ${ }^{9}$

As observed in the discussion of the nature of the international commitments above, it is sometimes hard to decide whether a certain management decision reflects the implementation of international commitments or national policy objectives; the two clearly evolve to a large extent in tandem. We also noted above that the regulatory measures of the bilateral regime between Norway and Russia have become ever more specific during the 1990s, and that a growing number of such measures have been co-ordinated between the two countries. Many of the decisions in the bilateral regime are only codified in a form whereby information about the decision is 
distributed by management or enforcement bodies to the fishing fleet by fax or telex. Typically, Sevryba or the enforcement body Murmanrybvod will inform all fishing vessels that Norway and Russia have agreed on a particular regulatory measure, and that the fishing vessels are obliged to comply with this decision from a specific date. In sum, the transformation of Russia's international obligations into national legislation seems to be characterised by inertia at the higher levels of the legal hierarchy and a multiplicity of legal documents at its lower levels. The problem is not so much inability to produce legal documents as the opposite: the ease with which presidential decrees, governmental resolutions, orders and provisions at ministerial level are issued probably reduces the probability of their enforcement. Hence, sending a telex from Sevryba to the fishing fleet of the Barents Sea might prove a more effective 'legal' measure than having the decision elevated to the level of presidential decree. This is further discussed in the section on target compliance below.

\section{The role of federal authorities}

There are currently two major federal bodies responsible for fisheries management and enforcement in the Russian Federation: the State Committee for Fisheries and the Federal Border Service, respectively. The former is the direct successor of the Soviet Ministry of Fisheries. The status of the federal body responsible for fisheries was reduced from that of a ministry to a state committee in connection with the break-up of the Soviet Union and the establishment of the Russian Federation in December 1991. As mentioned in Chapter 3, ministries and state committees are different types of 'independent' administrative bodies at the federal level; the ministries are placed higher in the political hierarchy since their leaders are members of the federal Government, but the state committees are not subordinate to any ministry. Hence, the federal body for fisheries management was 'degraded' in connection with the dissolution of the Soviet Union, but kept its status as a separate administrative body.

The State Committee for Fisheries is the federal body responsible for all aspects of fisheries management in the Russian Federation other than enforcement at sea (see below). Research institutes under the Committee collect and analyse data on fish stocks in waters under Russian jurisdiction. The Committee is responsible for regulatory action with a view to preservation of these fish stocks. It 
represents the Russian Federation in international fisheries negotiations - the Russian delegation to the Russian-Norwegian Fisheries Commission is always headed by the Chairman or Deputy Chairman of the Committee - and has the main responsibility for implementation of Russia's international obligations in fisheries. Clearly, the Committee has taken the task of overseeing implementation of these obligations seriously, but it is itself only marginally involved in implementation activities directed towards target groups. Most importantly, it decides major regulatory principles and has an important role in advisory or decision-making bodies where several agencies from both the regional and the federal level are represented. Moreover, it has the last word in all management decisions where other agencies are responsible for the practical work leading up to these decisions. For example, the Russian shares of the Barents Sea quotas are distributed among the federal subjects of Northwestern Russia by the so-called Technical-Scientific Catch Council and further distributed among shipowners in fisheries councils within each federal subject. However, the decisions of both the TechnicalScientific Catch Council and the fisheries councils have to be approved by the State Committee for Fisheries. ${ }^{10}$

The most conspicuous issue related to the status, responsibilities and performance of the State Committee for Fisheries in recent years is its fight to defend itself against interference from other federal agencies, in particular the Ministry of Economy and various 'power agencies'. First, an attempt was made to 'dissolve' it by temporarily depriving it of its status as a state committee and incorporating it into the Ministry of Agriculture and Foodstuffs as a department for fisheries in April 1997. Its status as state committee was restored in September 1998. Second, responsibility for enforcement at sea was transferred from Rosrybvod, a department under the Committee until then in charge of all enforcement activities, to the Federal Border Service in accordance with a presidential decree from August 1997 (Government of the Russian Federation 1997a). ${ }^{11}$ The decision to strip the Committee of responsibility for enforcement was followed by a media campaign, obviously arranged by the presidential administration, depicting it as corrupt and hence unfit for this type of task. ${ }^{12}$ However, the decision met with fierce resistance throughout the fishing industry and was only implemented a year later, on 1 July 1998. Third, the old tradition of appointing leaders of the Committee from within the fishery complex has 
been broken. During the last years of the 1990s, leaders of the Committee were changed frequently and primarily selected among candidates with their professional background from 'power agencies'. Employees of the Committee complain about the lack of 'professionals' in its leadership of recent years. ${ }^{13}$ Finally, the Ministry of Economy has recently 'forced' the State Committee for Fisheries to carry out a system for the sale of fishing quotas by auction, a procedure which the Committee is opposed to. ${ }^{14}$

In sum, the Russian Federation has a centralised system for fisheries management with the State Committee for Fisheries responsible for research and regulation and the Federal Border Service in charge of enforcement at sea. These federal bodies are responsible for the implementation of Russia's international fisheries obligations, but are only to a limited extent involved in implementation activities aimed at target groups; the practical work is for the most part delegated to representing agencies in the regions. The State Committee for Fisheries of the Russian Federation is the successor of the Soviet Ministry of Fisheries and reflects an attempt to continue the Soviet type 'industry-complex approach' to fisheries management, implying that one federal body is responsible for all aspects of fisheries. However, it has repeatedly had to defend itself from attacks aimed at reducing its traditional all-embracing influence on fisheries management. Its attempts to strike back have been partly successful. On the one hand, the Committee has succeeded in maintaining its own existence as a separate administrative body. On the other hand, it has been deprived of important tasks and had to accept interference from other federal agencies in areas that have traditionally been the responsibility of the Committee alone. One might rightly ask whether the problems of keeping one's 'head above water' in recent years has led to a displacement of goals: has survival in itself become the main objective of the Committee? At the very least, one could speculate whether its insecure existence has reduced the ability of the Committee to conduct effective fisheries management.

\section{The role of regional authorities}

Regional authorities, in Soviet times totally subordinate to federal authorities and in turn the CPSU, have traditionally had no role in the management of Northwest Russian fisheries. The 1993 Constitution also states that the management of natural resources in the 
EEZ is an exclusive federal responsibility. As we saw in Chapter 3, however, the role of regional authorities, especially the governors and their regional administrations, has been strengthened quite markedly during the 1990s. Have the regional administrations of Northwestern Russia attempted to expand their sphere of influence to include fisheries management?

The answer to this question is that they have indeed tried to do so, but that the results are more uncertain. A major attempt by the Northwest Russian federal subject to gain influence in fisheries management was made in the early 1990s. Murmansk, Arkhangelsk and Karelia established fisheries departments under their regional administrations in 1993-94 and demanded a say in the quota distribution, then dominated by Sevryba, which, in reality, functioned as a regional representative of the State Committee for Fisheries. In late 1993, the Governor of Murmansk Oblast boasted about having reached an agreement with the Committee that the regional administration was to take over Sevryba's management responsibilities. This conclusion appeared to be premature, but the regional administrations were from now on represented on the bodies where fishing quotas were distributed. ${ }^{15}$

The quotas of Russia's northern fishery basin have in recent years been distributed in two stages. The Technical-Scientific Catch Council divides the catch between the federal subjects and decides how much of the catch is to be allocated for 'basin purposes', i.e. to finance necessary tasks such as research and monitoring. Roughly 60 per cent of the catch has over the past years been allotted to Murmansk Oblast, whereas Arkhangelsk Oblast and the Republic of Karelia have received some 20 and 10 per cent, respectively. ${ }^{16}$ A certain share of the catch is usually designated for exchange purposes with the counties of Kaliningrad and Leningrad. Grigoriy Tishkov, ${ }^{17}$ long-standing managing director of Sevryba, was head of the Technical-Scientific Catch Council throughout the 1990s. The regional fisheries councils are led by the head of the fisheries division of the regional administration (i.e. representing the governor/republican president), but Sevryba has also largely maintained its position here. All decisions made in both the Technical-Scientific Catch Council and in the regional fisheries councils must be approved by the State Committee for Fisheries.

A central discussion topic in Russia's northern fisheries community at the end of the 1990s was the question of establishing a new 
'basin management body', i.e. an official body in charge of managing the entire northern fisheries basin. Scientists from the Kola Science Centre proposed creating such an organisation in a memorandum to the Murmansk Oblast administration in 1997. The 'basin body' would be based on the remains of Sevryba and be placed under both the State Committee for Fisheries and the executives of the four federal subjects in Northwestern Russia. In May 1999, the Murmansk Oblast administration made a formal proposal to the State Committee for Fisheries to establish a new 'basin body'. The proposal gained support at a meeting of the Northwestern Association in early autumn of that year, but it was suggested that the main office be located in St Petersburg. This led to more intensive lobbying from Murmansk. When Acting Chairman of the State Committee for Fisheries Yuriy Sinelnik visited Murmansk in October 1999, he announced to the press that a 'basin body' would be established in Murmansk as a trial project and that similar organisations would later be created in the other fisheries basins of the country. A possible outcome would be its creation, thus 'strengthening' the regional fisheries management with an organisation that is 'stronger' than Sevryba and the regional administrations are today, while keeping federal authorities' control and sanction possibilities for decisions made in the region. As of autumn 2001, the 'basin body' had not yet been established.

In conclusion, the regional authorities of Northwestern Russia have during the 1990s above all displayed great aspirations to get involved in fisheries management. They have established their own fisheries departments, although each employs only a handful of people, which have achieved at least a certain measure of influence over the most important practical management measures, namely the distribution of quotas. However, the regional fisheries departments are not involved in the elaboration of other regulatory measures or enforcement. Apart from their participation in the regional fisheries councils that distribute the quotas among shipowners in the region, they above all seem to perceive their role as an advocate of the fishing industry of the region articulating its cause in relation to federal authorities. The regional legislatures of Northwestern Russia have played a very minor role in fisheries management. The regional Duma of Murmansk Oblast has passed a law on coastal fisheries (Murmansk Oblast 1997b), but it was later annulled by the regional legal authorities. Former Director of Sevryba Grigoriy Tishkov was elected to the 
Murmansk regional Duma in 1997, but this does not seem to have had any influence on fisheries management in the region.

\section{The role of federal agencies in the region}

Federal agencies located in the region have traditionally played a very important role in the management of Northwest Russian fisheries. As noted earlier in this chapter, Sevryba was originally created as the General Directorate of the Soviet Ministry of Fisheries in Northwestern Russia. Although its name was changed several times, it retained its role as both an association of all fishing industry actors and the main fisheries management body of the region throughout the Soviet period. Sevryba was the 'extended arm' of the Ministry of Fisheries in the region, in other words: a typical 'implementing' body. It 'governed' the entire fishing industry of the region down to the specifics of deciding where each particular vessels was to fish at any given time. It was in control of the distribution of quotas between the shipowners (or 'fishing organisations', as they were designated in the Soviet period) of the region and issued other regulatory measures on behalf of the Ministry of Fisheries.

The privatisation of Sevryba in 1992 initiated a process that in a few years rendered the status and competence of the association as both an industry and a management actor highly unclear. An immediate consequence of privatisation was loss of control over the enterprises that formed the association. The administration of Sevryba, having employed more than five hundred people in the 'good old Soviet times', saw its number reduced to a few dozen in the course of less than five years, since most financial and 'industrial' tasks were now taken care of at the company level. Hence, in the first years after privatisation it appeared important for Sevryba, i.e. the administration of the association, to maintain its role in the management process (since the other former tasks had been lost to its founding companies). When the regional administrations of Northwestern Russia in 1993-94 attempted to get involved in the management process, Sevryba retaliated vigorously, arguing that the fish stocks in the EEZ are indisputably a federal responsibility and that practical regulatory experience in the region lay within Sevryba, not the governors' apparatus. As the previous section showed, regional authorities were partly successful in their aspirations and acquired some influence in the process of quota distribution. However, Sevryba retained considerable power in this area along with continued responsibility for most other regulatory issues. 
In the mid-1990s, the Sevryba administration acquired its first vessel purchased on a bare-boat charter basis, the Sevryba-1. The administration was then in a position to secure favourable quota conditions for its own vessel, registered it in Cyprus, and suddenly emerged as a small, but lucrative one-boat fishing company. At the same time, the management tasks were increasingly handed over to the regional administration (see previous section). The institutional identity of Sevryba was again changing; with the emerging possibilities for Sevryba- 1 and several sister ships already under way, it seemed increasingly to be ready to let go of management responsibilities.

Another important federal agency located in the region is the enforcement body Murmanrybvod. It is subordinate to Rosrybvod, the department of the State Committee for Fisheries responsible for enforcement. Murmanrybvod has traditionally been in charge of the enforcement of fishery regulations in the rivers and lakes of Murmansk Oblast, in the Barents Sea and in international convention areas where the Northwest Russian fishing fleet conducts fishery, notably NEAFC and NAFO. ${ }^{18}$ Most of the 300-400 employees of Murmanrybvod have been involved in the enforcement of fishery regulations in the rivers and lakes on the Kola Peninsula; only some twenty inspectors have been assigned to enforcement tasks in the Barents Sea and the international convention areas.

As follows from the section on the role of federal authorities above, responsibility for fisheries enforcement at sea in the Russian Federation was transferred from Rosrybvod to the Federal Border Service in August 1997, a decision made effective as of July 1998. In the northern fishery basin, the Murmansk State Inspection of the Arctic Regional Command of the Federal Border Service was established to take care of fisheries enforcement. The main argument put forward by supporters of the reorganisation in Northwestern Russia was that the Border Service had far more and far faster vessels than Murmanrybvod's two old rebuilt fishing vessels. As in the rest of Russia, the decision to strip the traditional enforcement body of responsibility for enforcement at sea met with fierce resistance also in the northwestern region. Both the fishing industry and the rest of the fishery management apparatus supported Murmanrybvod in its battle with the 'intruders' from the 'power agency' of the Border Service. ${ }^{19}$ As in Sevryba's battle with the regional administrations, Murmanrybvod's main argument was that the necessary expertise and experience were to be found in the 'traditional' body. Murmanrybvod 
turned out to be less successful than Sevryba - the Federal Border Service was obviously a stronger opponent than the regional administrations - and was forced to relinquish responsibility for enforcement at sea. However, it is only responsibility for physical inspections at sea that has been transferred to the Border Guard. Murmanrybvod is still in charge of keeping track of how much of the quotas has been caught by the individual shipowner at any one time. ${ }^{20}$ It has also retained its responsibility for the closing of fishing grounds in areas with excessive intermingling of under-sized fish, a very important regulatory measure in both the Russian and Norwegian part of the Barents Sea. Finally, Murmanrybvod is still responsible for enforcement in international convention areas. In practice, Murmanrybvod places its inspectors on board Northwest Russian fishing vessels that intend to fish in the NEAFC of NAFO areas.

A fisheries department has been established under the Northwestern Federal Okrug, the new administrative layer introduced by President Putin in May 2000 (see Chapter 3). This department, located in St Petersburg and mostly occupied with the co-ordination of fisheries research, has not been given a role in the regulatory process. It is not represented in the Joint Russian-Norwegian Fisheries Commission or the Technical-Scientific Catch Council.

In sum, federal agencies located in the region appear as the main participants in Russian public authorities' efforts to manage the Northwest Russian fishing fleet, including efforts to implement the country's international obligations. The federal bodies themselves interfere only to a limited extent in the management process, and regional authorities have not proven 'strong' enough to gain any significant influence. The old general directorate, Sevryba, retained much of its influence well into the 1990s notwithstanding its ever more dubious formal status in the regulatory process. Murmanrybvod has been stripped of its enforcement tasks at sea, but is still an important actor in the regulation and enforcement of Northwest Russian fisheries. A new federal agency has been established in the region in connection with the enforcement reorganisation, the Murmansk State Inspection of the Arctic Regional Command of the Federal Border Service. Hence, most practical implementation activities' directed towards the target groups of Northwest Russian fisheries take place in Murmansk - by Sevryba, Murmanrybvod and the Border Service's Murmansk State Inspection - although they have to be approved of by federal authorities. 


\section{The role of others}

The distinction between public authorities and others might be somewhat blurred in the former Soviet Union since much of the administrative structure of the plan economy has been maintained, formally or informally, into the era of the Russian Federation. The experience with Sevryba is a good case in point. Formally, Sevryba was an association of all major fishing enterprises in Northwestern Russia; more or less informally, it has during the 1990s emerged at times as the 'extended arm' of the State Committee for Fisheries in Northwestern Russia and at times primarily as a small fishing company pursuing purely commercial interests. The 'traditional' actors of Northwest Russian fisheries - i.e. all parties involved except 'intruders' of recent years, notably the Federal Border Service and the regional administrations - are in Russia clearly perceived as above all belonging to the 'fishery complex'. The division between governmental agency and 'user group' hence becomes less relevant. ${ }^{21}$ Nevertheless, we will in the following attempt to give an overview of how actors other than public authorities have influenced the management of Northwest Russian fisheries during the 1990s.

\section{Target groups}

It should be fairly obvious by now that target groups - i.e. the region's fishers and their representative bodies - have traditionally been highly involved in the management process of Northwest Russian fisheries. Sevryba has at one and the same time been the main fisheries management body in the region and the association of its fishers. The 1990s showed how organisational constructions like Sevryba have had to struggle in the post-Soviet period to defend their existence; partly they have clung on to their old functions, partly they have adapted to the new environment and created a 'commercial' basis for themselves. It seems fair to conclude that Sevryba's role in fisheries management in recent years has been significantly reduced. At the same time, Sevryba no longer emerges as a representative of the large shipowners in the region; although formally still constituting the association Sevryba, these enterprises now appear as independent industry actors. Hence, to the extent that Sevryba maintains its old management tasks, it represents the 'lucrative, small fishing company' that its administration has created for itself in recent years, rather than the larger shipowners of the 
region. On the other hand, these industry actors - Murmansk Trawl Fleet, Murmanrybprom, Arkhangelsk Trawl Fleet Base etc. (see above) - have increased their direct influence on fisheries management. Whereas they were earlier mainly represented through Sevryba, they now participate in their own right in the bodies responsible for quota distribution in Russia's northern fishery basin. Table 4.2 shows which governmental bodies and user groups are represented at various levels in the quota distribution process. A main observation is that all large shipowners, as well as the Union of Private Fishing Enterprises in the North - representing the smaller shipowners - are represented at international, inter-regional and regional level. However, these bodies are occupied mainly with quota distribution; the influence of user groups on other management issues is limited. It is also unclear how 'strong' user groups emerge vis-à-vis governmental agencies in these corporate bodies.

A conspicuous trend of late has been the increased influence of some of the small shipowners organised in the Union of Private Fishing Enterprises in the North. Probably the most famous example is shipowner Vladimir Gusenkov. He used his position as a nouveau riche to gain broad popular support though his cheap fish programme, an initiative aimed at providing fish products at reasonable prices to the population of Northwestern Russia. In 1997, he was elected to the regional duma. Two years later, he succeeded in becoming one of two deputies from Murmansk Oblast to the state duma. Before ending up in Moscow, Gusenkov had become an influential person in Northwest Russian fisheries. Allegedly, he paid for much of the costs of organising negotiations in the Russian-Norwegian Fisheries Commission in Murmansk in November 1999 and was in return given representation in the Russian delegation. ${ }^{22}$ After very difficult negotiations - Norway wishing to follow the recommendation of the ICES scientists to reduce the cod quota drastically, and Russia to disregard the scientific advice - the cod TAC was set at nearly four times above the scientists' initial recommendation. Negotiations stalled for several days, and Norway eventually agreed on the high quota level only with reference to 'the importance of fisheries to the crisis-ridden population of Northwestern Russia' (Ministry of Fisheries 1999, Article 5.1). In the subsequent negotiations between Russia and Norway in November 2000, Gusenkov allegedly emerges as an informal leader of the Russian delegation, again insisting on a quota far above the scientific recommendations. This not only reflects the increased influence of Russian target groups and regional actors in 
Table 4.2 The main decision-making bodies of Northwest Russian fisheries and governmental bodies and user groups represented in them

\begin{tabular}{|c|c|c|}
\hline Decision-making body & $\begin{array}{l}\text { Represented } \\
\text { governmental bodies }\end{array}$ & $\begin{array}{l}\text { Represented user- } \\
\text { groups }\end{array}$ \\
\hline $\begin{array}{l}\text { The Joint } \\
\text { Norwegian-Russian } \\
\text { Fisheries Commission } \\
\text { (responsible for } \\
\text { establishing TACs for } \\
\text { the joint stocks in the } \\
\text { Barents Sea) }\end{array}$ & $\begin{array}{l}\text { The State Committee for } \\
\text { Fisheries (head of } \\
\text { delegation) } \\
\text { The Oblast/republican } \\
\text { administrations of } \\
\text { Murmansk, } \\
\text { Arkhangelsk and } \\
\text { Karelia } \\
\text { VNIRO (federal fisheries } \\
\text { research institute) } \\
\text { Regional fisheries } \\
\text { research institutes } \\
\text { from Murmansk and } \\
\text { Arkhangelsk (PINRO, } \\
\text { SevPINRO) } \\
\text { Regional control bodies } \\
\text { in Murmansk and } \\
\text { Arkhangelsk } \\
\text { (Murmanrybvod and } \\
\text { Sevrybvod) } \\
\text { Sevryba }\end{array}$ & $\begin{array}{l}\text { The administration of } \\
\text { Sevryba } \\
\text { Murmansk Trawl Fleet } \\
\text { Murmanrybprom } \\
\text { Arkhangelsk Trawl Fleet } \\
\text { Karelrybflot } \\
\text { Murmansk Collective } \\
\text { Fishing Fleet } \\
\text { The Union of Private Fishing } \\
\text { Enterprises in the North }\end{array}$ \\
\hline $\begin{array}{l}\text { Technical-Scientific Catch } \\
\text { Council (responsible } \\
\text { for distributing quota } \\
\text { shares between } \\
\text { Murmansk, } \\
\text { Arkhangelsk and } \\
\text { Karelia) }\end{array}$ & $\begin{array}{l}\text { Sevryba (leader) } \\
\text { The Oblast/republican } \\
\text { administrations of } \\
\text { Murmansk, } \\
\text { Arkhangelsk and } \\
\text { Karelia } \\
\text { Regional fisheries } \\
\text { research institutes in } \\
\text { Murmansk and } \\
\text { Arkhangelsk (PINRO, } \\
\text { SevPINRO) } \\
\text { Regional control bodies } \\
\text { in Murmansk and } \\
\text { Arkhangelsk } \\
\text { (Murmanrybvod and } \\
\text { Sevrybvod) }\end{array}$ & $\begin{array}{l}\text { The administration of Sevryba } \\
\text { Murmansk Trawl Fleet } \\
\text { Murmanrybprom } \\
\text { Arkhangelsk Trawl Fleet } \\
\text { Karelrybflot } \\
\text { The collective fishing fleets } \\
\text { of Murmansk, } \\
\text { Arkhangelsk and Karelia } \\
\text { The Union of Private Fishing } \\
\text { Enterprises in the North }\end{array}$ \\
\hline $\begin{array}{l}\text { The regional fishery } \\
\text { councils (responsible } \\
\text { for distributing quota } \\
\text { shares between } \\
\text { individual companies } \\
\text { in the respective } \\
\text { regional entities) }\end{array}$ & $\begin{array}{l}\text { The oblast/republican } \\
\text { administration in the } \\
\text { respective regional } \\
\text { entities (leader) } \\
\text { Sevryba } \\
\text { Research and control } \\
\text { bodies from the } \\
\text { respective regional } \\
\text { entities }\end{array}$ & $\begin{array}{l}\text { The administration of } \\
\text { Sevryba } \\
\text { The largest fishing } \\
\text { companies in the } \\
\text { respective regional entities } \\
\text { The collective fishing fleets } \\
\text { of the respective regional } \\
\text { entities } \\
\text { The Union of Private } \\
\text { Fishing Enterprises in the } \\
\text { North }\end{array}$ \\
\hline
\end{tabular}

Source: Hønneland (2001). 
the formulation of the Russian position in the bilateral negotiations with Norway; ${ }^{23}$ more than anything, it reflects the growing 'malignity' of the problem at hand (see the section above on the nature of the problem). With increased political and economic insecurity on the one hand and the possibility of rapid personal profit on the other, target groups might end up less willing to think about their own and their community's long-term interests. We return to this question in the discussion on implementation performance below.

\section{NGOs and research institutes}

The number of external agents, i.e. those other than governmental bodies and user groups, involved in Russian fisheries management is very limited. NGOs are practically absent in Northwest Russian fisheries. The only exceptions are labour unions and various types of fishers' associations, but they have no role in fisheries management, nor in implementation of international obligations. ${ }^{24}$

The main 'external' agents in Northwest Russian fisheries management are fisheries research institutes at the federal and region level, notably the All-Russian Scientific Institute for Fisheries and Oceanography (VNIRO) in Moscow and the Knipovich Scientific Polar Institute for Marine Fisheries and Oceanography (PINRO) in Murmansk. It is indeed doubtful whether these institutions should be labelled 'external'; they are both directly subordinate to the State Committee for Fisheries. ${ }^{25}$ While VNIRO is the main supplier of scientific input to the Committee at the federal level, PINRO is the major participant in the management process at the regional level in Northwestern Russia. The state of the fish stocks in the Northeastern Atlantic and the Barents Sea are constantly assessed by PINRO researchers, often in co-operation with Norwegian marine scientists. The results of their investigations are discussed by ICES' Advisory Committee for Fisheries Management (ACFM) and further channelled to national authorities as assessments of the fish stocks and recommendations for their exploitation. Hence, the advice that Russian and Norwegian authorities receive concerning the Barents Sea fish stocks is based on the work of both Russian (primarily from PINRO) and Norwegian scientists. In other words: the State Committee for Fisheries, as the main governmental agency responsible for Russia's fisheries management, receives scientific input from an international organisation (ICES) which is based on the work of scientists from an institution administratively subordinate to itself. 
The most striking feature of PINRO's role in the management process in recent years is the disregard by Russian authorities of ICES' scientific advice. The Joint Russian-Norwegian Fisheries Commission has increasingly since the mid-1990s established TACs well above the scientific recommendations after pressure from the Russian party. This clearly demonstrates the impotency of Russian scientists in the face of government authorities and other pressure groups within the Russian delegation.

The role of PINRO scientists in the management process is not reduced to their co-operation with foreign colleagues in ICES. PINRO is highly integrated in the 'day-to-day' management of the Barents Sea fisheries. Most importantly, PINRO's research ships assist the exploration fleet Sevrybpromrazvedka in finding concentrations of fish for the fishing fleet. The unclear distinction between government and user groups discussed above is also reflected in the way fishers perceive the role of marine science and enforcement. In the West, it is generally considered legitimate (or even preferable) for the two to have somewhat divergent interests from the user groups (being obviously more concerned about protection of the resource base than exploiting it), at least to the extent that user groups are thought to be solely concerned with their own interests (see above). In Northwest Russian fisheries, marine science and enforcement bodies still largely seem to be perceived by fishers as belonging to the same unity - the fishery complex - as themselves. For instance, to the extent one sees discontentment among Russian Barents Sea fishers about marine science, it seems to be directed towards the alleged inability of scientists to predict the presence of fish in a short-term perspective. ${ }^{26}$

\section{Joint implementation}

Joint implementation in this context denotes implementation activities directed towards Russian targets and performed by Russian agents in co-operation with foreign nationals. A problematic aspect of discussing joint implementation in Northwest Russian fisheries is that decisions made at one level can be regarded as implementation of decisions made at higher levels. For instance, should research and regulatory activities between Russians and Norwegians under the framework of the bilateral regime be perceived as joint implementation? We are inclined to answer this question in the negative, but 
maintain that co-operation between representatives of the two countries in efforts to implement decisions made at the bilateral level should indeed be regarded as such.

Throughout the 1990s, joint implementation between the fisheries enforcement bodies of Norway and Russia in the Barents Sea has expanded consistently. The Permanent Committee under the Joint Commission was established in 1993 as a response to Russian overfishing in the Barents Sea. ${ }^{27}$ When most Russian vessels started to deliver their catches in Norway, the old system for quota control in Russia - based mainly on catch control in port - proved inadequate. The Permanent Committee established a system for exchange of catch data between the enforcement bodies of the two states which reintroduced a mechanism for effective quota control in Northwest Russian fisheries. Co-operation with their Norwegian counterparts seems to have remained an important component of the work of Northwest Russian fisheries enforcement bodies throughout the 1990s. First, most Russian vessels still deliver their catches in Norway, so Russian enforcement bodies depend on data from Norwegian authorities to keep track of how much of their quotas the vessels have fished. Second, Norwegian enforcement bodies regularly assist their Russian counterparts in organising physical catch controls when Russian vessels land their fish in Norwegian ports. ${ }^{28}$ Third, many enforcement tasks - such as routines for closing and opening of fishing grounds - have been co-ordinated between the authorities of the two states. Fourth, Norwegian enforcement bodies have partly assisted their Russian counterparts materially and financially. Interestingly, federal agencies in the region predominate in the Russian delegation to the Permanent Committee: the State Committee for fisheries was only represented in connection with the establishment of the Committee in 1993. ${ }^{29}$ Enforcement co-operation between Norway and Russia can generally be characterised as successful. As far as problem-solving is concerned, the effects are uncertain, but the manner in which co-operation functions today clearly represents an improvement over the earlier situation (Hønneland 2000b).

\section{Implementation performance and target compliance}

The main question to be asked in this section concerns the degree to which Russian authorities have succeeded in implementing their international obligations related to the activities of the Northwest 
Russian fishing fleet. First, have Russian authorities succeeded in setting up a system for fisheries management in accordance with their international obligations? Second, if so, has this system functioned as intended? Can any tendency be traced as to the type of management body (e.g. at what level of governance) that functions most satisfactorily? Third, have implementation activities affected the behaviour of target groups? Another major issue to be analysed is whether problems in implementation can be ascribed to the nature of the problem or the quality of implementation activities.

From global agreements Russia has concluded derive obligations, inter alia, to manage fisheries in the country's 200-mile EEZ in accordance with the principle of MSY, to establish TAC for each fish stock within the EEZ, to co-operate with other coastal states in the management of shared stocks, and to promote compliance with fishery regulations among all vessels under Russian flag. Already prior to the conclusion of the LOSC, the Soviet Union had a system in place for fisheries management and enforcement, which could now be adjusted to contribute to Soviet implementation of the new international obligations. Naturally, the Soviet Ministry of Fisheries was the central actor at the federal level. As far as the northern basin is concerned, a regulatory body existed in Sevryba, an enforcement body in Murmanrybvod and a fisheries research institute in PINRO. The tasks of these bodies were now adapted to the new surroundings, reflected mainly in the specific research, regulatory and enforcement obligations following from the newly established bilateral regime with Norway. PINRO's scientific results were already integrated in the work of ICES and were now used as a basis for recommendations to the regulatory authorities of the two countries. Sevryba was already the main regulatory body in the region and was now given the task of implementing regulations agreed upon in the Joint Fisheries Commission, notably to oversee the distribution of Russian quota shares. Murmanrybvod was already involved in monitoring of fishing activities, but was now given responsibility for enforcement in the entire ocean area up to 200 miles from shore. Hence, the Soviet Union took the necessary administrative steps to adjust the existing system for fisheries management to the new international obligations. Although data on the functioning of this system during the Soviet period are poor, it seems fair to assume that research, regulatory and enforcement bodies were well suited (in terms of competence and material resources) for their respective 
tasks, that they performed these tasks quite satisfactorily, and that target compliance was generally high. ${ }^{30}$ The command system of the plan economy generally implied a high degree of control over the activities of target groups. Moreover, the latter had less incentive to cheat than they would have had in a market economy. Notably, all involved agencies belonged to the 'fishery complex', administratively subordinate to the Ministry of Fisheries.

In the post-Soviet period, three features stand out in the development of Northwest Russian fisheries management, one partly following from the other: the diffusion of management responsibility; the degeneration of implementation performance; and the reduction in target compliance. We have seen throughout this chapter how the established fisheries management system during the postSoviet period has been challenged from different angles. Various 'power agencies', notably the Federal Border Service, have successfully challenged the task of the State Committee for Fisheries and its subordinate regional agencies to conduct enforcement at sea. The Ministry of Economy has interfered in the quota allocation process through its introduction of a system for auctions of fish quotas. The regional administrations of Russia's federal subjects have, somewhat less successfully, attempted to take over the management role of federal agencies located in the region.

A decline in implementation performance has followed partly from the fact that the 'newcomers' are less fit for their tasks than the traditional agencies, and partly from confusion following unclear division of responsibility between 'new' and 'old' management bodies. The former refers to poor standards in both competence and material resources. The regional administrations have had only a handful of persons of varying backgrounds employed in their fisheries departments; in comparison to Sevryba's large and wellexperienced staff they have had little to show for their efforts. More apparent is the lack of experience and resources in the Border Service (whose tasks have also come to be more extensive than those of the regional administrations). For one thing, officers in the Murmansk State Inspection of the Federal Border Service generally lack experience in fisheries management and enforcement; this has partly been compensated for by transfer of some of Murmanrybvod's inspectors. More apparent is the lack of material resources to maintain presence at sea. Quite contrary to the intentions of the reorganisation of the enforcement system, the presence at sea by monitoring vessels 
declined since the Border Guard took over this duty in 1998. Precise data for presence at sea and inspection frequency are not available, but Jørgensen (1999, pp. 88-90) estimates that the Border Guard performed around 160 inspections at sea in 1998, which represents a significant reduction compared to an estimated 700-1,000 annual inspections at sea by Murmanrybvod prior to the reorganisation. For several months on end during 1998, not a single enforcement vessel was present on the fishing grounds in the Russian part of the Barents Sea. Officials of the Border Service explain this as lack of funds to purchase fuel. Critics question the genuineness of the Border Service's will to play a role in fisheries management. The result of the reorganisation has in any event so far been a tangible reduction in the effectiveness of Russian enforcement in the Barents Sea. ${ }^{31}$

Unclear task delineation might also have led to a reduction in implementation performance although it is more difficult to point to concrete effects here. Again the conflict between Rosrybvod/ Murmanrybvod and the Federal Border Service is the most striking example. After the decree prescribing the reorganisation was issued in 1997, both agencies continued for a long period to perform enforcement duties, but at a low intensity and without co-ordination between them. A lack of co-ordination has remained a problem also after the decree was actually implemented - i.e. when a clear delineation of duties was established - in 1998. The same can partly be said about the relationship between Sevryba and the Murmansk regional administration, particularly in the early and mid-1990s, when a pretty fierce battle was going on between the two institutions. A kind of 'peace' was settled towards the end of the decade when Sevryba proved 'stronger' than its opponent but at the same time conceding to the latter a certain influence in quota allocation. The 'confusion' again mounted when Sevryba started to lose interest in management issues as its role as 'lucrative, small ship-owner' became more important. As mentioned, it is difficult to point to concrete management deficiencies as a result of the 'confusion'; we can only assume that a certain reduction in performance took place.

Data on target compliance in Russian fisheries are not publicly available. We assumed above that target compliance was generally high in the Soviet period, partly as a result of lacking incentives to cheat. It seems fair to conclude that the overall compliance level in the Russian part of the Barents Sea has decreased in the post-Soviet era. For one thing, Norwegian authorities in 1992 took extra steps 
to calculate the total Russian catch in the Barents Sea that year. ${ }^{32}$ The figures indicated over-fishing by the Russians at a rate of more than 100,000 tonnes. Over-fishing hence constituted one quarter of the total cod quota in the Barents Sea in 1992. Russia had 170,000 tonnes at its disposal, of a TAC of 396,000 tonnes, after internal quota exchanges with Norway. This estimate was supported by export statistics, which indicated that close to the total Russian cod quota in the Barents Sea had been exported to Norway. At the same time, considerable quantities had been exported to other Western countries. Some cod had also been landed in Murmansk. The sudden rise in over-fishing coincided with Russian fishers starting to deliver the bulk of their catches abroad, primarily in Northern Norway. At the same time, the direct export of their product increased the incentives for fishers to underreport their catches (since they were paid better abroad), and reduced the chance for Russian authorities to keep track of the catches since control had traditionally been conducted in connection with landings of fish in Russian ports. The joint implementation (i.e. enforcement) practice described above halted as anticipated the opportunity for Russian fishers to conceal their real catches for Russian authorities when delivering in Norway. Nevertheless, the increased incentive to violate the regulations as compared to Soviet times has probably led to a reduction in target compliance. Combined with the significant reduction in performance of the Russian enforcement system notably the absence of monitoring vessels at sea for considerable periods - there is reason to assume that the fall in target compliance is not insignificant. Interviews with Norwegian and Icelandic fishers who operated in the Russian part of the Barents Sea in 1997-99 indicate that a considerable illegal fishery of undersized fish took place in periods when enforcement vessels were absent (Jørgensen 1999, pp. 105-6).

In conclusion, a certain degeneration in implementation capabilities and performance among Russian authorities has taken place in the northern fishery basin throughout the 1990s. The traditional 'fishery complex' management bodies, which had taken care of implementation in a satisfactory way until the break-up of the Soviet Union, were now challenged by other governmental agencies wanting a piece of the budgetary cake and a growing 'malignity' of the problem. So far, the 'traditional' agencies - mainly the State Committee for Fisheries, Sevryba and Murmanrybvod - emerge as more 
successful in their implementation activities than the 'newcomers', notably the Federal Border Service and the regional administrations. The former are far better off in terms of competence and, to some extent, also material resources than the latter. To the extent that 'newcomers' have taken over, this seems to have led to a reduction in implementation performance and target compliance. On the other hand, with rumours of corruption in the State Committee for Fisheries and Sevryba having become more of a commercial actor than a management body, it seems rash to simply regard the various reorganisations as errors of judgement.

\section{Notes}

1 See Nilssen and Hønneland (2001) for a recent overview of the postSoviet restructuring of the Northwest Russian fishing industry.

2 Admittedly, Soviet fishers were rewarded for over-fulfilling the production plans, but their personal economic gains were far smaller than is the case today. Moreover, since goods were considerably scarcer than purchasing power, the minor extras paid for this were probably of little significance.

3 Of course, this depends on what you compare with. Our point is that this case lies somewhere between cases where the target is either three pipelines or a million cars.

4 For instance, it is relatively easy with modern surveillance equipment to detect a vessel operating in an area closed for fishing. The underreporting of a few tonnes of fish is, on the other hand, relatively difficult to discover due to the difficulty of conducting precise physical checks of the catch once it is stored in the ship's hold.

5 The Northwest Russian fishing fleet operates mainly, but not exclusively, in the Barents Sea.

6 As of 2002, the regional leaders will not themselves take place in the Federation Council; instead, they will appoint their representatives. This change was part of Putin's 'spring reorganisation' of 2000 (see Chapter 3), but has not been implemented at the time of writing.

7 The contents of the draft Fisheries Act has not been made public. However, some details are known from Russian media, and the authors have also received some information in conversations with involved actors.

8 For instance, quota allocation has in recent years been regulated by a preliminary provision issued by the State Committee for Fisheries (State Committee for Fisheries 1999a) while monitoring and enforcement activities are regulated by a so-called 'order' from the same committee (State Committee for Fisheries 1999b). 
9 Famous is the story of Yeltsin's presidential decree that presidential decrees are henceforth to be complied with. In the fisheries sector, there are numerous decrees and orders aimed at redirecting the deliveries of fish to the home market, which have not been enforced.

10 In practice, the decisions of the Technical-Scientific Catch Council and the regional fisheries councils are almost always approved by the State Committee for Fisheries.

11 A 'service' (sluzhba) is also an independent federal agency immediately below ministry level. Although often referred to as a 'military' agency, the Federal Border Service is not answerable to the Ministry of Defence.

12 An example is the major headline on the front page of Izvestiya on 12 September 1997: 'The Mafia Has Beaten the Fishery Inspection. Can the Border Guard Beat the Mafia?'

13 It should be mentioned that this new strategy is more like the Western tradition of using political all-rounders for ministerial posts. For most Russians, used to ministers who are specialists in their field of responsibility, this is a new thing.

14 This is an example of how more general legislation appearing before the Fisheries Act reduces the scope of action for fishery management authorities. The provision on quota auctions is printed in Rossiyskaya Gazeta, 13 January 2001.

15 See Hønneland (1998) for a more detailed presentation of these events.

16 See Hønneland and Nilssen (2001) for a discussion of quota allocation in Russia's northern fishery basin.

17 Tishkov was ousted as director of Sevryba in late 2000.

18 Similar bodies are found also in Arkhangelsk Oblast and the Republic of Karelia, Sevrybvod and Karelrybvod, but these are responsible for enforcement of fishery regulations in rivers and lakes only (as well as the White Sea in the case of Sevrybvod). Responsibility for ocean fisheries by the Northwest Russian fishing fleet is wholly under Murmanrybvod.

19 A representative of the fishers in Murmansk made the following statement to Polyarnaya Pravda (19 September 1997, p. 1): 'The situation in our fishing industry is still difficult. The last six months' disintegration of the federal management bodies renders it extremely alarming, too.'

20 Fish quotas are in Russia given to shipowners, not to individual vessels.

21 See Hønneland and Nilssen (2000) for a further discussion of this dilemma.

22 In the protocol from the session, Gusenkov is identified as member of Murmansk regional duma (Ministry of Fisheries 1999). It seems rather odd to include deputies from the regional legislatures in the delegation since these have no role in fisheries management. Representatives from the legislatures of the other federal subjects of Northwestern Russia are 
not included. This supports the argument that his role as shipowner and economic benefactor was more important for his inclusion in the Russian delegation than his status as representative of the regional duma.

23 Interview data indicate that representatives of federal authorities in the Russian delegation were more prepared to make a compromise with Norway than were representatives from Northwestern Russia.

24 Both labour unions and fishers' associations are mainly engaged in welfare work.

25 So-called 'departmental' (vedomstvennye) research institutes are very common in Russia. They are subordinate to various governmental agencies and intended to serve their needs. More basic scientific research is carried out at institutions under the Russian Academy of Science.

26 In an article in the newspaper Polyarnaya Pravda, fishers from Murmansk complain that they were not warned by the scientists that the big cod had already migrated into the Norwegian zone: 'If no fish is found in the ocean, then fishers are convinced that science is to blame' (Polyarnaya Pravda, 18 February 1998, p. 1). The message is: the main task of marine scientists is to help us fishers.

27 See Hønneland $(1998,2000 b)$ for a more detailed account of these events.

28 These inspections are defined as Norwegian while the Russia inspectors participate as observers. However, Russian authorities may file charges against a vessel for violations discovered during such an inspection.

29 During the greater part of its existence, the Russian delegation to the Permanent Committee has been headed by the director of Murmanrybvod. Sevryba and PINRO are also represented. In 1999, a representative of the Murmansk State Inspection of the Arctic Regional Command of the Federal Border Service was given a place in the delegation.

30 One could discuss whether the decisions of the Joint Fisheries Commission are in accordance with international obligations of the two countries (e.g. whether they reflect international principles for fisheries management), but we limit our discussion here to decisions made at national level in Russia.

31 The reader might ask: 'Why did Russia choose this solution when the old system functioned well enough?' We see two possible answers to this question. One is that it indeed makes sense to transfer responsibility for enforcement to an agency independent of the rest of the fisheries management system as long as the latter is surrounded by allegations of corruption. Another answer is that there is probably no uniform strategy behind the decision to strip the State Committee for Fisheries/ Rosrybvod of its enforcement capacity; rather, the reorganisation was the result of a fight over budget funds. With increased responsibility come increased funds, and the Border Guard was more interested in 
the latter than the former, the argument - often employed by representatives of the 'fishery complex' - goes.

32 The Norwegian inspectors used the catch logs of the Russian vessels to calculate the individual vessel's total catch that year. Normally, they would only have been interested in catches taken in Norwegian zones, but on this occasion they included catches taken in the Russian EEZ. 